\title{
THE ROLE OF INSURANCE IN ORGANIZATION OF TOURIST TRAVEL
}

\section{Aleksandra Stojaković}

Singidunum University, PhD candidate, Belgrade, Serbia,

Underwriter in DDOR Novi Sad
Correspondence:

Aleksandra Stojaković

e-mail:

astojakovic0812@gmail.com
Abstract:

This paper describes the role of insurance in the organization of tourist traveling. Within the framework of sustainable development, two more indicators related to tourism destinations, namely tourist security and satisfaction, should be added to these factors. Insurance largely participates in the organization of tourist travels because it represents a factor that facilitates planning and selection of tourism destinations. By surveying stands and perceptions of the insured parties and tourist agencies, the insurance companies conduct research on tourist activities and provide recommendations in order to enhance insurance penetration in tourism, which ensures safe traveling and environment.

Keywords:

insurance, tourism, coverage, organization, travel insurance.

\section{INTRODUCITON}

In the European Union, tourism represents one of the largest sectors with a $9 \%$ share in the consumption and it is also one of five export areas in $83 \%$ of countries worldwide, as well as the major source of the foreign currency inflow in $38 \%$ countries (Pavlović, 2014). According to the 2013 World Economic Forum report, Serbia is ranked $89^{\text {th }}$ on the list of global travel and tourism competitiveness index which covers 140 countries (WEF TTCI, 2013), while the report for the year 2015 covers almost the same competitive position of Serbia, being ranked $95^{\text {th }}$ on the list of 141 countries (WEF TTCI, 2015). Starting from these facts and bearing in mind the importance of insurance in the economic development, the aim of this study is to explore the role of insurance in tourism through a presentation of different types of insurance in various tourism segments and insurance perception by travel agencies. The paper also explores the conduct of insurance companies to tourist activities and gives recommendations for article improvement of penetration of tourism insurance for the purpose of providing a safer environment for investors. A regards this matter, both travelers and tourism agencies have the common goal, to achieve and maintain the safety and satisfaction of travelers of the planned trip.

Insurance as an activity may have a favorable impact on the safety of all participants in tourist travel and protect the passengers from potential travel risks. Adverse and disastrous events happen in the world, which causes huge damage to international tourism destinations. These sudden and catastrophic accidents have a serious impact on tourism and the 
economy of the countries and such adverse events in the tourist business activities have turned into a big problem for continuation and development of this business. In this context, safety, aimed at reducing the financial consequences, plays an important role (Lemarechal et al., 2015).The issue of availability of insurance in the tourist industry is directed not only towards tourist companies, but also transportation companies. At the same time, the major challenge is the coverage of commercial and general liability, i.e. risk coverage and achievement of insurance coverage profitability.

It may be said that the main objective of concluding insurance for tourism companies is based on risk management and assessment. Increasing awareness of the insured parties as passengers, tourism companies and transportation companies is recommended as well as participation of the government in increasing the penetration of insurance in tourist industry. As it is wellknown, the international tourism agencies are developing and changing from one year to another whereas the number of people and participants in the tourism offer is constantly rising (Čekrlija, 2012).

\section{RESULTS AND DISCUSSION}

\section{Risk management in tourism}

Risk is defined as a possibility of occurrence of certain situation that could have an impact on the fulfillment of objectives. All the risks have the potential to get out of control, which creates the crisis. Therefore, the rational approach to risk management is important and it implies determination of the level of risk exposure that is acceptable for tourism and clients (Easterbi-Smith $e t$ al., 2008), identification of threats for the activity itself and for clients, and the selection of adequate strategies, implementation of these strategies and the appropriate response to extraordinary situations. Risks in tourism may be divided into four basic groups: for the institutional environment of the tourist and complementary companies (e.g. terrorism, violence $e t c$.), unforeseen circumstances in organization of travels (e.g. traffic accidents, lack of protection, earthquakes, floods), passengers as individuals (e.g. visit to dangerous places and similar), physical hazards and risks that threaten the environment (e.g. tourists who are not aware of the natural characteristics of places and destinations they are visiting, failure to take adequate medical and other measures). Insurance companies need to ensure communication with travel agencies. In communication with their clients, who are potential insurers, favourable results can be achieved for insurance market both in terms of quality and price of services (Gajski, 2013).

The usual way of confronting the risk includes the following options: risk acceptance, risk reduction, risk transfer and evasion. Risk acceptance occurs in cases when the frequency and range of risk is small and only if the risk consequences can be managed without any negative impact on the destination, i.e. perception of the visitors (Jovanović, 2010). Risk reduction can be controlled by the change of the risk probability, i.e. probability of reducing the effects (e.g. decrease of the fire results in a hotel with the evacuation plans, training of the personnel etc.) and by increasing the flexibility. The transfer of risk is used when there are considerable consequences (such as injury, damage to property), and the risk is transferred, on the whole or partly to the insurance companies (Barjaktarović et al., 2013). Risk evasion occurs if the frequency and size of the risk is high to the extent that the operation is suspended or withdrawn from the tourist offer. In fact, the purpose of insurance is to compensate or reduce the financial losses and maintain the continuity of tourism activities to restore the normal operations and cost-effective manner of doing business. Figure 1 discloses how the resources and risks are covered by the concluded insurance policies and how business transactions are covered. This requires subsequent decision making about the critical areas in order to remain competitive with other tourist enterprises for more efficient and effective model of tourism development management and its activities (Popesku, 2015, p. 9). 
In modern tourist offer, there is a growing risk of terrorism and political instability, which poses a serious threat to tourism industry. Not only the Arab countries, but also the cities of the European continent, such as London, Madrid, Paris (Lemarechal et al., 2015) are facing the increased number of terrorist attacks and insecure and unstable environments and therefore, these risks have caused enormous damage to tourism on the global scale and they represent a challenge in the situation aimed at preserving the business. Travel companies have suffered considerable losses since the number of tourist visitors has been reduced at certain destination, the latest indicators are the frequent terrorist attacks in France (Lemarechal et al., 2015).

Here we may also refer to natural disasters, which are not routine events, and they require the appropriate reaction and organisation, where the insurance and risk assessment are related to performance of the tourism activity due to reduced revenues or the number of visitors. The primary intention is to reduce the possibility of damage and negative impact to avoid risk. However, the main reason is the threatened survival of tourism companies, because many of them have gone bankrupt or have stopped working altogether following such disasters. Insurance companies can provide valuable assistance in the matters of risk management in tourism (Kaushalya et al., 2014, p. 631). It is important to protect an organization from financial consequences, i.e. losses that reduce business potentials (Popesku, 2015, p. 13) and also to find a model for achievement of favourable business results and enhanced competitiveness.

\section{TYPES OF INSURANCE IN TOURISM ACTIVITY}

Travel insurance is the insurance aimed at covering the costs of medical treatment, surgery or death in the course of travel. It also includes covering the costs of the lost luggage, air accidents and other similar losses during a trip, either abroad or in the country. The travel insurance can usually be arranged 24 hours before departure for the specified number of days in travel arrangements (DDOR, 2016), or the policy may cover an unlimited number of trips in a given time period (AXA, 2016), or for instance, several days of travelling a year (DDOR, 2016). Travel health insurance may be concluded by persons aged 85 and below, and it generally follows the payment of the insurance premium and ends depending on the contracted travel period or trip completion. The business policy of insurers differs and there is a lower and higher volume of coverage of medical costs. Nevertheless, they are generally higher for the countries with extremely high costs of medical treatment, such as the US.

There are several types of travel insurance depending on different risks of the insurance contracting parties in tourism. The most common travel insurance is concluded by passengers themselves i.e tourists departing for different international destinations, including as follows (Konsument, 2012, p. 12):

- Travel-health insurance abroad,

- Insurance against accidents on the trip,

- Insurance against cancellation of the trip,

- Luggage insurance on the trip.

\section{Private voluntary travel insurance}

\section{Travel health insurance}

This insurance is concluded as a voluntary, private insurance for an individual or a family planning a tourist trip abroad. It includes the insurance coverage abroad for a medical treatment in case of acute illness or an accident. The contracted insurance amount is the limit for the costs of the outpatient treatment, medicines, hospital treatment or a surgery, medically justified return transport of the injured person or transport of a deceased person. The insurance does not include the treatment that may be predicted as well as rehabilitation or special services. Chronic diseases that already existed prior to the travel or risk-taking sports are often explicitly excluded or included in the insurance only to a limited extent (Konsument, 2012, p. 12).The most important thing is to react on time when a medical problem occurs during the trip and that the insurer is contacted as soon as possible. The number of reported claims, based on the data DOOR (2016), the payment of damages are ranging from 2 milion RSD in 2013 till 1,5 milion RSD in 2016.

There are often intermediary agencies abroad responsible only for the travel-health insurance and they provide assistance (CORIS, 2016) and advice to the policyholders at certain destinations on behalf of insurance companies.

\section{Travel insurance against accidents}

This type of insurance facilitates the financial compensation after an accident during a trip. The compensation is given only in case of the permanent disability, by means of compensation provided for the rescue and return to home, as well as in case of death, the highest 
ammount covers 30.000 Eur (CORIS, 2016). Small amounts are usually envisaged for the coverage of this insurance and this it can be concluded that private travel insurance is recommended in case of an accident.

\section{Cancellation of insurance}

This insurance compensates the costs to a traveler in case he/she is forced to withdraw from travelling under certain conditions such as accidents, diseases or death of a close family member. This insurance must usually be concluded simultaneously with the travel reservation. A precondition for this insurance to be covered afterwards is the prevention from travelling suddenly occurred and that this could not have been anticipated by the insured party, as in the case of unannounced interruption of employment, the insurance covers part of the amount that was paid to the agency, when their client withdraws from travelling (Helona, 2016; Milenium, 2016; DDOR, 2016).

\section{Luggage insurance}

Luggage safety is important and this insurance provides protection in case of damage, destruction or loss (e.g. robbery, theft) of all items and luggage that is usually carried to a trip for personal purposes. Jewelry, watches, furs, technical devices (cameras, film and video equipment, lap-top computers, mobile phones) as well as sports devices are covered by this type of insurance only if they are securely stored and personally supervised or used so that their seizure by the third party is not possible. The insurance company will pay the compensation amounting to the present value of the insured items, for instance, the official procedure in Air Europa (2009) airlines when luggage is delayed more than 24 hours is to pay compensation in the amount from 100 to 200 EUR. Also, the specific provisions apply to the luggage in the car or in the camping area. Generally, the insurance in tourism may have the positive and negative impacts, which are largely conditioned by the planning and organization of travels to certain destinations (Maksin et al., 2012).

Figure 2 and 3 show the intensity of conclusion of the travel insurance in the summer period with the insurer DDOR Novi Sad, using the data collected until the end of July 2016 and during the summer seasons in the period from 2013 to 2015, applying the methods of statistical analysis of the data of the observed insurance company.

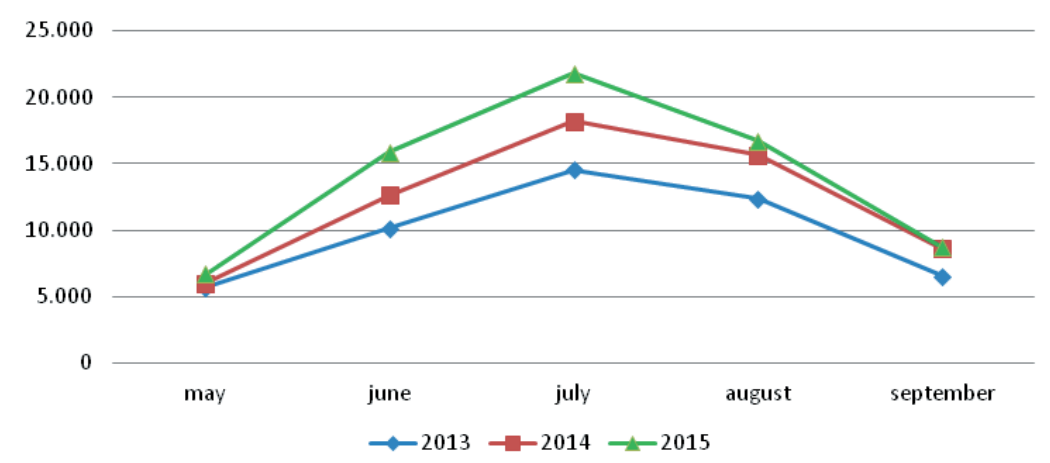

Figure 2. Realization of road assistance \& travel insurance policy in the summer season for the period 2013 - 2015 - DDOR Novi Sad (number). Source: DDOR (2016b)

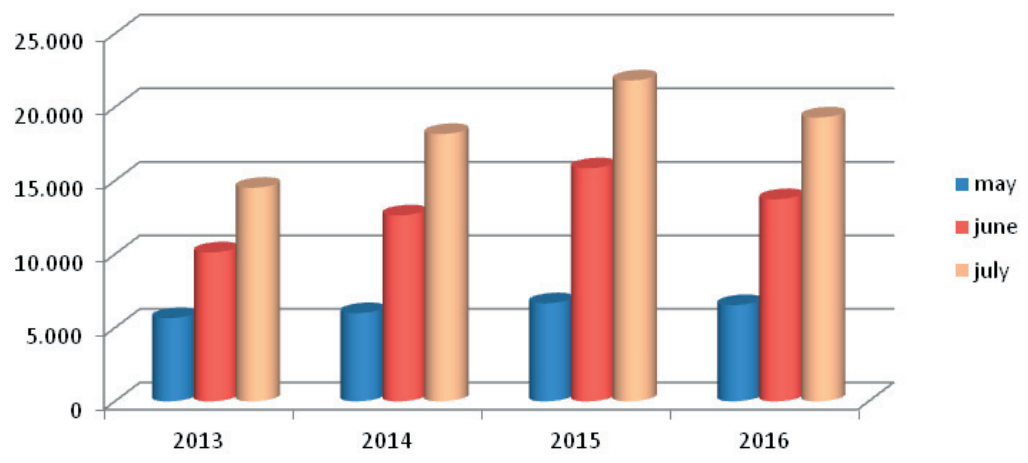

Figure 3. Realization of road assistance \& travel insurance policy in May, June, July for the period from 2013 to 2016 - DDOR Novi Sad (number)

Source: DDOR (2016b) 


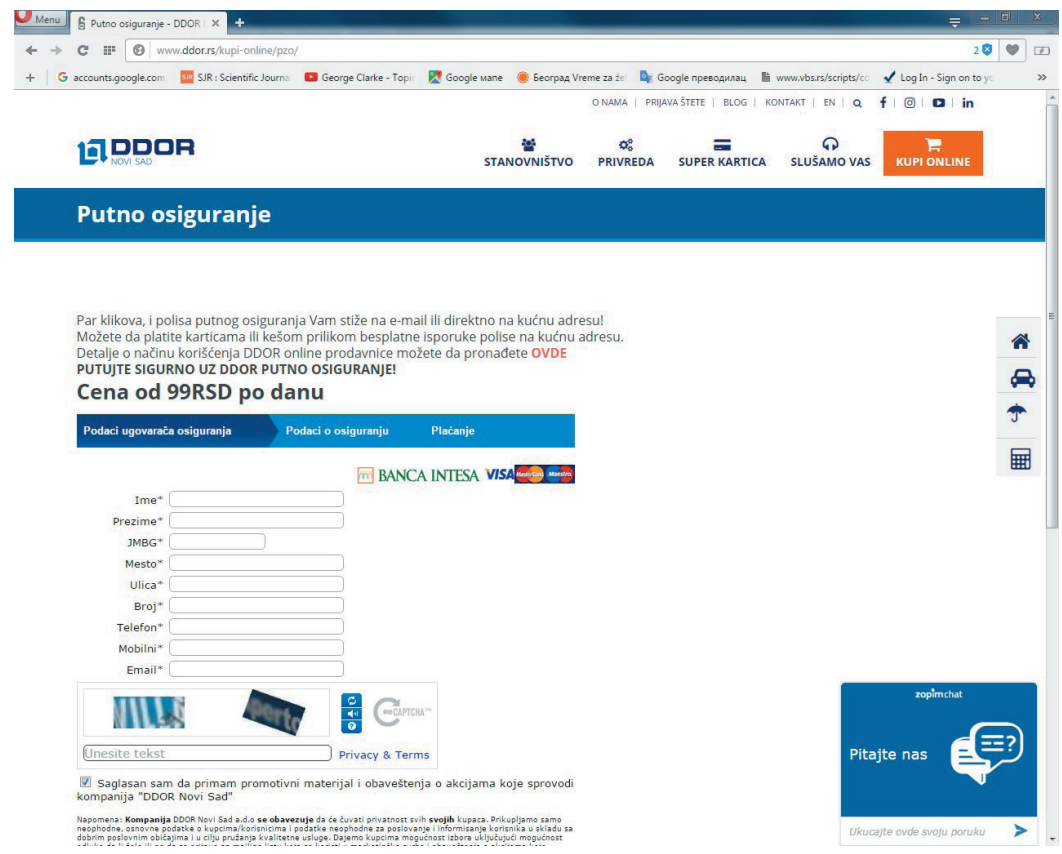

Figure 4. Online shop on the website of insurer DDOR Novi Sad Source: http://www.ddor.rs/kupi-online/pzo/

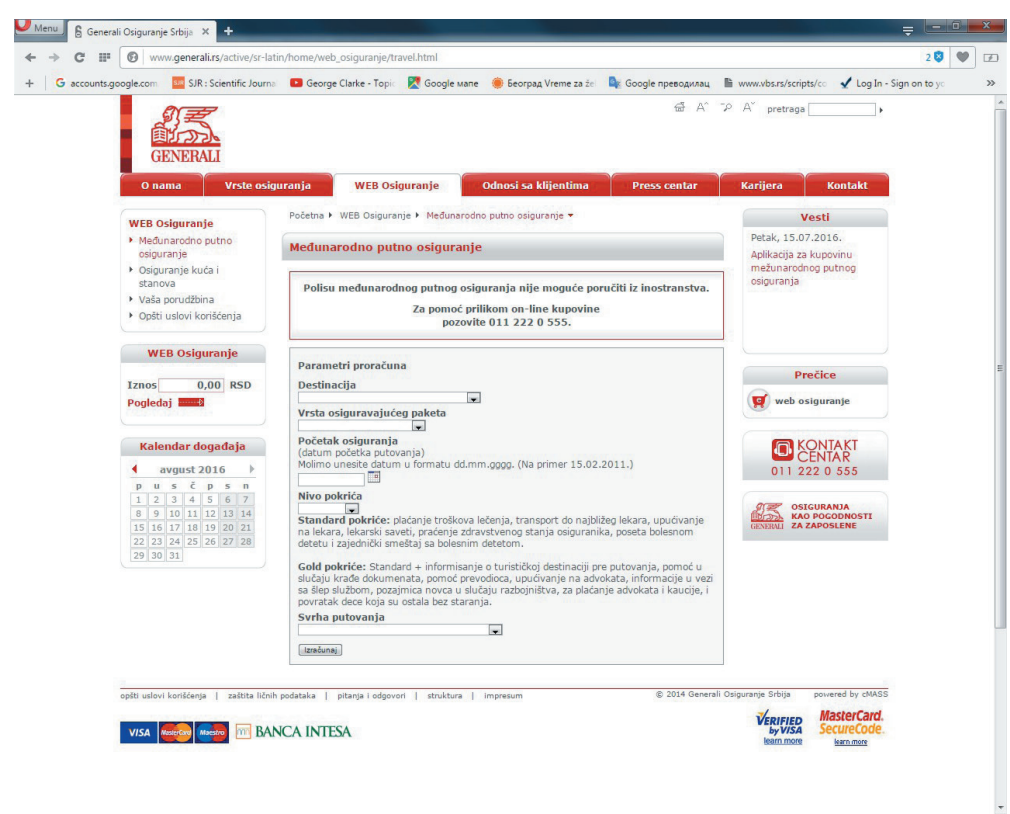

Figure 5. Online shop on the website of insurer Generali Insurance Serbia Source: http://www.generali.rs/active/sr-latin/home/web_osiguranje/travel.html

Drastic increase in the number of sold travel policies from the beginning of June to early July is noticeable, which indicates strong demand for private insurance during the most intense period of the summer season. As of August, the need for this insurance is decreasing.

Contribution to popularization of the travel-health insurance can be seen in development of e-insurance in the direction of online shopping and faster conclusion of travel insurance by interested users so as to make the organisation of tourist travel more easier and efficient, in order to prevent extraordinary costs and stressful situations. Policyholders themselves may conclude travelhealth insurance policies by contacting the insurance company directly or through the Internet, although the tourist package with additional private medical insurance is often done through tourist organizations, which cooperate with certain insurers on behalf of their clients. Figure 4 and 5 show the affordable programs offering online sale of private medical insurances. 
Mandatory travel insurance

Mandatory insurance by the owners

of means of transport

Provisions of the Law on Compulsory Insurance in Traffic (Službeni glasnik RS, 51/2009) regulate mandatory insurance by the owners of the means of transport (buses, planes, trains) aimed at covering the damage caused to passengers and third parties due to:

- death,

- bodily injury,

- health problems,

- damage to their property,

- destruction of or damage to cargo and checked in luggage (Paragraf, 2016).

Such insurance contract can be concluded for a limited period of time or for the travelling period and it covers the damage caused to passengers, cargo and checked in luggage, as well as the damage due to war and terrorism risks (DDOR, 2016). The share of this group insurance in the total insurance premium is $0.6 \%$ for many years (DDOR, 2013; DDOR, 2014; DDOR, 2015).

Liability insurance of travel agencies in case of insolvency and responsibility in case of the damage caused to the traveler (the travel guarantee)

In accordance with the Law on Tourism (Službeni glasnik RS, 84/2015), conditions apply for the claims by policyholders due to its insolvency and liability for the damage caused to passengers. Insolvency is inability to pay the mature due debts, which results in the financial blockade of the tour organizer (travel agency) and the amount to be paid is higher than the funds they have at disposal.

On the basis of the foregoing, travel agencies are required to conclude this type of insurance, which provides security to passengers through the following compensations:

1) the cost of necessary accommodation, meals and return of travelers from destinations in the country and abroad to the place of departure;

2) claim of the funds paid by passengers on the basis of the tourist travel contract - which the organizer fails to realize;

3) claim of the funds paid by passengers in case of trip cancellation by the customer, in accordance with the general travel conditions;

4) claim of the difference between the contracted travel price and travel prices lowered in propor- tion to non-execution or incomplete execution of the services provided by the travel program (Milenijum, 2013).

The same goes for the responsibility of the insured party for damage caused by the travel agency to the traveler through failure to fully or partially or disorderly meet the commitments related to implementation of services covered by the General Terms and the travel program, in accordance with the law regulating the tourism sector (Službeni glasnik RS, 84/2015) the form of compensation for:

1) claim of the funds paid by passengers based on the contract on tourist travel which the insured party fails to realize,

2) claim of the difference between the contracted price of travel and travel prices in proportion to the reduction of non-execution or incomplete execution of the services covered by the travel program (Milenijum, 2013).

It is obviously important for the owners of tourist or transport companies to have adequate insurance in all aspects of their business operations in the tourism industry, because they are facing challenges of market conditions and specialized risks. Accordingly, the insurance has relevant importance in the field of tourism business. Making a decision to buy the insurance in organization of tourist trips depends on external factors (Stojković, 2013), such as the legal and regulatory laws that determine the conditions of insurance, while some other types of insurance remain voluntary.

\section{CONCLUSION}

The need for insurance is larger nowadays, especially for the voluntary insurance because it covers more risks involved in the insurance policy. Therefore, it is important to pose a question as to whether passengers and travel agencies have insurance and how to provide assistance in the tourist travel. This paper aims to identify the role of insurance in the tourism industry through the study of attitudes and perceptions of travel agencies, to make a survey of the conduct of insurance companies in travel deals and activities, and to make recommendations for improving the penetration of insurance in tourism while ensuring a safer environment for investors in tourism and the economy in general (Kordić et al., 2015, p. 35). Although insurance is considered to be one of the vital factors for success of the process of planning and organizing travels, tourist companies do not have sufficient knowledge about insurance and they should communicate more with insurance companies, 
which are able to draw their attention to their needs and requirements as well as to the specific features of tourism business. On the other hand, insurance is an economic instrument used to avoid a collapse of the tourist and economic development of the country, because the risks include the whole society.Travel companies should treat insurance as an important aspect of creating competitiveness, because they are exposed to the increased risk of needs for the capital, which creates an additional instability.

Finally, we may say that it is important to monitor the progress and improvements of the insurance penetration among tourism enterprises (insured parties) and insurance companies (insurers), through the awareness programs, public education, conferences, inciting insurance premiums and broader risk coverage, with special emphasis on the tourism industry, due to the large scale business risk with the increased efficiency of insurers.

\section{REFERENCES}

AXA. (2016). Putno osiguranje. Retrieved July 25, 2016 from https://www.axa.rs/za-mene-i-moju-porodicu/putno-osiguranje/.

Barjaktarović, L., \& Jeremić, Lj. (2013). Finansijska kriza i upravljanje rizicima osiguranja i bankarstva. Beograd: Ekonomski institut.

Čekrlija, S. (2012). Turizam kao faktor održivog razvoja opšti pristup odnosu ulaganja i siromaštva. Svarog, 5, 249-257. doi:10.7251/SVR1205249C.

CORIS. (2016). Osiguranje u Srbiji: Sva osiguravajuća društva na jednom mestu. Retrieved July 22, 2016, from http://osiguranje.cu.rs/beograd/coris/.

DDOR Novi Sad (2016). Putno osiguranje. Retrieved July 25, 2016, from http://www.ddor.rs/kupi-online/pzo/.

Easterbi- Smith, M., Torp, R., \& Jackson, S. (2008). Research management. London: Sage Publications.

Gajski, Z., \& Milijević, N. (2013). Budućnost osiguranja je i zdravstveni turizam. Svijet osiguranja, 4/2013. Retrieved July 21, 2016, from http://www.svijetosiguranja.eu/hr/clanak/2013/4/buducnost-osiguranja-je-i-zdravstveni-turizam,322,10665.html

Generali Osiguranje Srbija. (2016). Međunarodno putno osiguranje. Retrieved July 25, 2016, from http:// www.generali.rs/active/sr-latin/home/web_osiguranje/travel.html.

Helona. (2016). Osiguranje od otkaza putovanja. Retrieved July 27, 2016 from http://www.helona.rs/osiguranje-od-otkaza/.

Jovanović, V., \& Delić, U. (2010). Karakteristike manifestacija i njihov uticaj na razvoj turizma u Srbiji. Singidunum revija, 7(2), 203-220.
Kaushalya, H., Karunasena, G., \& Amarathunga, D. (2014, September). Role of insurance in post disaster recovery planning in business Community. Procedia Economics and Finance. 18/2014(626-634). 4th International Conference on Building Resilience. Retrieved July 27, 2016, from PubMed database on the http://www.sciencedirect.com/science/article/ pii/S2212567114009848.

Versicherungsverband Österreich. (2012). Potpuno osigurani: stručni pojmovi jednastavno objašnjeni. Retrieved July 27, 2016 from http://www.vvo.at/vvo/vvo. nsf/sysPages/x83AE7AFF3B266B91C1257D880044 728B/\$file/Konsument_Spezial_2012_Serbisch.pdf.

Kordić, N., Živković, R., Stanković, J., \& Gajić, J. (2015). Safety and security as factors of tourism destination competitivness. Book of Proceedings: Singidunum University International Scientific Conference Tourism Destination Competitiveness, SITCON. doi:10.15308/ sitcon-2015-34-38.

Lemarechal, C., Mang, E., Maniere, E., \& Ramic, A. (2015). The terrorist attacks, a problem for the tourism industry in France. TourMag. Retrieved July 25, 2016 from http://www.tourmag.com/The-terrorist-attacks-a-problem-for-the-tourism-industryin-France_a71934.html

Maksin, M., Pucar, M., Milijić, S., \& Korać, M. (2012). Održivi razvoj turizma u Evropskoj uniji i Srbiji. Beograd: Institut za arhitekturu i urbanizam Srbije.

Milenijum osiguranje. (2013). Uslovi osiguranja od odgovornosti turističkih agencija za slučaj insolventnosti $i$ odgovornosti za slučaj štete nastale putniku (Garancija putovanja). Retrieved July 25, 2016 from http:// www.alturs.rs/wp-content/uploads/2013/01/preuzmite-dokument-1.pdf.

Paragraf. (2016). Zakon o obaveznom osiguranju. Retrieved July 25, 2016, from http://www.paragraf.rs/ propisi/zakon_o_obaveznom_osiguranju_u_saobracaju.html.

Pavlović, S. (2014). Indikatori održivog razvoja za turistističke destinacije. Svarog, 9, 254-265. doi:10.7251/ SVR1409254P.

Popesku, J., \& Pavlović, D. (2015). Adapted integrated model of destination competitivness. Book of Proceedings: Singidunum University International Scientific Conference Tourism Destination Competitiveness, SITCON. doi:10.15308/sitcon-2015-9-17

Službeni glasnik RS. (2009). Zakon o obaveznom osiguranju u saobraćaju. Službeni glasnik RS br. 51/2009.

Službeni glasnik RS. (2014). Zakon o osiguranju. Službeni glasnik RS br. 55/04, 70/04, 61/05, 85/05, 101/07, 107/09, 99/11, 119/12, 139/14.

Službeni glasnik RS. (2015). Zakon o turizmu. Službeni glasnik RS br. 36/2009, 88/2010, 99/2011, 93/2012, $84 / 2015$.

Službeni glasnik RS. (2015). Zakon o zdravstvenom osiguranju. Službeni glasnik RS, br. 106/2015. 
Stojković, M. (2013). Organizacija rada turističkih agencija. Retrieved July 25, 2016 from http://www.turizamiputovanja.com/organizacija-rada-turistickihagencija/

Šipovac, Z. (2014). Ugovor o putnom zdravstvenom osiguranju. Srpska pravna misao, 20(47), 285-305. doi:10.7251/SPM1447285S.

World Economic Forum. (2013). The Travel and Tourism Competitiveness Report 2013. Retrieved July 22, 2016 from http://www3.weforum.org/docs/WEF TT_Competitiveness_Report_2013.pdf.
World Economic Forum. (2015). The Travel and Tourism Competitiveness Report 2015. Retrieved July 22, 2016 from http://ep00.epimg.net/descargables/2015/05/06/ f2c1e517ce56a6453171d3a9d1b1da05.pdf 